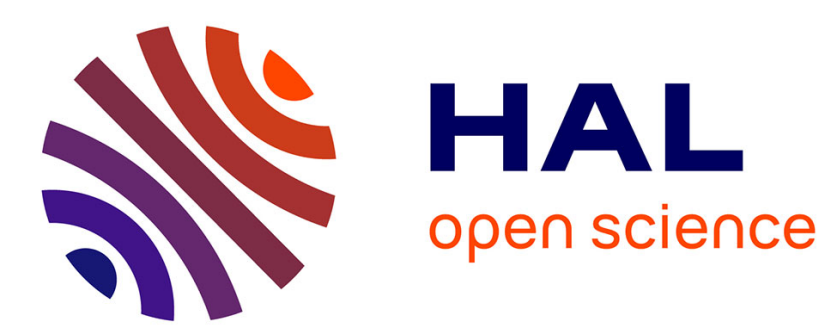

\title{
Efficacy of theophylline in patients affected by low-adenosine syncope
}

Michele Brignole, Diana Solari, Matteo Iori, Nicola Bottoni, Régis Guieu, J. C. Deharo

\section{- To cite this version:}

Michele Brignole, Diana Solari, Matteo Iori, Nicola Bottoni, Régis Guieu, et al.. Efficacy of theophylline in patients affected by low-adenosine syncope. Heart Rhythm, 2016, 13 (5), pp.1151-1154. 10.1016/j.hrthm.2015.12.016 . hal-01317462

\section{HAL Id: hal-01317462 \\ https://hal-amu.archives-ouvertes.fr/hal-01317462}

Submitted on 17 Jun 2016

HAL is a multi-disciplinary open access archive for the deposit and dissemination of scientific research documents, whether they are published or not. The documents may come from teaching and research institutions in France or abroad, or from public or private research centers.
L'archive ouverte pluridisciplinaire HAL, est destinée au dépôt et à la diffusion de documents scientifiques de niveau recherche, publiés ou non, émanant des établissements d'enseignement et de recherche français ou étrangers, des laboratoires publics ou privés. 


\section{Heart Rhythm 2016}

\section{Efficacy of theophylline in patients affected by low-adenosine syncope}

Michele Brignole, $\mathrm{MD}^{1}$, Diana Solari, $\mathrm{MD}^{1}$, Matteo lori, $\mathrm{MD}^{2}$, Nicola Bottoni ${ }^{2}$, Regis Guieu, $\mathrm{MD}^{3}$, Jean Claude Deharo, $\mathrm{MD}^{3}$

1. Department of Cardiology, Ospedali del Tigullio, Lavagna, GE

2. Department of Cardiology, Arcispedale S. Maria Nuova, Reggio Emilia

3. UMR MD2, Aix Marseille University, and Institute of Biological research of the French Army (IRBA), Marseille, France

Total word count: 2583 (excluding front page)

Statement. We declare no relationship with industry. The study was not funded.

Corresponding Author:

Michele Brignole, MD,

Department of Cardiology, Ospedali del Tigullio, via don Bobbio 25, 16033 Lavagna, Italy.

Telephone: +390185329567

Email: mbrignole@asl4.liguria.it 


\begin{abstract}
Background.Adenosine, an ATP derivative, may be implicated in some kinds of unexplained syncope. In patients with normal heart, normal ECG and recurrent sudden-onset syncope without prodromes have been shown to present with lowplasmatic adenosine levels and a high susceptibility to exogenous adenosine.The term "low-adenosine syncope" has been launched to describe this distinct clinical entity.

Objectives. We decided to investigate whether chronic treatment of these patients with theophylline, a non-selective adenosine receptor antagonist, results in clinical benefit.

Methods. We report on the prolonged clinical observation of 6 "low-adenosine" syncope patients (mean age $50 \pm 20$ years, 4 females) treated with oral theophylline within the therapeutic range of $12-18 \mu \mathrm{g} / \mathrm{ml}$. We were able to make an intrapatient comparison between a period with and a period without theophylline therapy.

Results. In five patients, symptoms disappeared and the number of prolonged asystolic pauses detected by implantable loop recorder (ILR) fell impressively from a median of 1.11 per month (interquartile range 0.4 -1.8)during 13 months of no-treatment (range 2-36) to 0 per month(0-0.7) during 20 months of theophylline treatment (range 6-120). The $6^{\text {th }}$ patient, was unresponsive to theophylline therapy, and a different mechanism of syncope was hypothesized.

Conclusion. In this small series of highlyselected patients affected by syncope with low circulating adenosine levels, theophylline proved to be an effective therapy in most patients. The logical inference is that the adenosine pathway has a causal role in the mechanism of syncope in such patients.
\end{abstract}




\section{Introduction}

Adenosine, an ATP derivative, may be implicated in some kinds of unexplained syncope. Patients with unexplained syncope of sudden onset, a normal heart and normal ECG (so-called "unexplained syncope, no prodromes and normal heart")have been shown to be different from vasovagal syncope patients $(1,2)$. Rather, their clinical and biological features are close to those observed in patients affected by idiopathic paroxysmal AV block (3).Patients with syncope without prodromes and normal heart and patients with idiopathic AV block have an adenosine profilewhich is opposite to that observed in vasovagal syncope patients and is characterized by very low plasmatic adenosine values, low expression of $\mathrm{A}_{2 \mathrm{~A}}$ adenosine receptors and a high induction rate of transient complete heart block during exogenous injections of adenosine (4). Unlike in vasovagal syncope patients, tilt testing is usually negative (4). These forms of syncope have been labelled "low-adenosine syncope" (1) and this terminology will be used throughout this manuscript.

Since patients with low plasma adenosine levels are highly susceptible to exogenous and endogenousadenosine (2-6) we wanted to investigate if treatment with theophylline, a nonselective adenosine receptor antagonist, should result in prevention of syncopal recurrences. We found the opportunity to test this hypothesis in a highly selected subset of patients who will be described in this manuscript

\section{Description of patients}

We report on the prolonged clinical observation of 6 "low-adenosine" syncope patients (mean age $50 \pm 20$ years, 4 females) treated with oral theophylline within the therapeutic range of 12 $18 \mu \mathrm{g} / \mathrm{ml}$. The patients had common major clinical features: 1) a long-standing history (median 8 years, range 3-30 years) of recurrent unexplained syncopes without prodromes, normal heart and normal ECG; and 2) baseline values of plasmatic adenosine $(0.11 \pm 0.03 \mu \mathrm{mol} / \mathrm{L})$ well below the $5^{\text {th }}$ percentile of the value of normal subjects $(0.40 \mu \mathrm{mol} / \mathrm{L})$ [4]). Multiple episodes of paroxysmal AV block and sinus-atrial arrest were documented at the time of (pre)syncopes in 4 and 1 patients, respectively; in another patient, documentation of the mechanism was lacking, as no ECG monitoring was active at the time of symptoms.Patient characteristics are listed in Table 1.

We had the opportunity to perform an intrapatient comparison between a period with and a period without theophylline therapywith the support of prolonged ECG monitoring in the majority of them (Table 2).The follow-up of all patients is updated to July 2015.

Specifically:

- patient \#1 was seen in 1995 and followed up for 20 years. In 1995, Holter monitoring fortuitously recorded idiopathic paroxysmal AV block, which was reproduced on the adenosine triphosphate test (ATP test). For the next 10 years, she underwent theophylline therapy, during which time she had no syncopal recurrences. In 2005, soon after discontinuing theophylline, she had a syncopal recurrence, for which she received an implantable loop recorder (ILR); over the next 3 years, 2 further episodes of idiopathic paroxysmal AV block 
with long asystolic pauses up to $22 \mathrm{~s}$ were documented. In 2008, she received a permanent pacemaker and has remained asymptomatic since that time.

- patient \#2 participated in a 2-period cross-over trial (Off-On-Off-On therapy) under ILR monitoring: episodes of idiopathic paroxysmal AV block decreased from 19 (max pause $7 \mathrm{~s}$ ) off therapy to 4 (max pause 3 s) on therapy (Figure 1 and Figure 2 panels A, B and C).

- patient \#3 had 8 syncopes in the 2 years off therapy and no recurrence during the subsequent 2 years on therapy. Only when she started theophylline did she receive an ILR, which never recorded any arrhythmias.

- in patient \#4, episodes of idiopathic paroxysmal AV block dropped from 27 (max pause $7 \mathrm{~s}$ ) off therapy to 0 on therapy (Figure $\mathbf{3}$ ).

- patient \#5 was the only patient who had a sinus-atrial arrest documented with an ILR: two consecutive pauses due to sinus arrest of $3 \mathrm{~s}$ and $6 \mathrm{~s}$ were preceded by few beats of slowing of sinus rate; he remained free of symptoms and arrhythmias during the 20 months of theophylline therapy.

- we also report the case of a woman (case \#6) who had very frequent (daily) pre-syncopes during a 3-year observation period; on several occasions, she underwent 24-hour Holter monitoring, which, on each occasion, detected multiple episodes of paroxysmal asystolic AV block preceded and followed by PR interval prolongation and $2^{\text {nd }}$ degree AV block (Figure 4). Since the patient refused pacemaker implantation, she was treated with oral theophylline 600 $\mathrm{mg} /$ day for 1.5 months: although her symptoms persisted, the episodes of asystolic AV block declined from 14 (longest pause $9.2 \mathrm{~s}$ ) on pre-therapy Holter monitoring to 7 (longest $6.7 \mathrm{~s}$ ) on monitoring during theophylline.

To summarize, in 5 patients, who presented with asystole during long-term continuous ECG monitoring, symptoms disappeared and ECG-documented pauses were impressively reduced during the theophylline period in comparison with the no-treatment period.The $6^{\text {th }}$ patient was unresponsive or hypo-responsive to theophylline therapy (Table 2).

\section{Discussion}

In thisseries of case reports, theophylline appearedeffective in five out of six patients with recurrent sudden onset (pre)syncope and who presented with the common biological characteristic of low circulating adenosine levels. Since theophylline is a non-selective antagonist of purinergic receptors, we hypothesize that purinergic receptors are involved in the mechanism of syncope in such patients.

Like other methylated xanthine derivatives, theophylline is a non-selective $A_{1}$ and $A_{2}$ adenosine-receptor antagonist (10). When plasma adenosine values are far below the constant of dissociation (KD) value of $0.7 \mu \mathrm{M}$ for $A_{1}$ adenosine receptors $\left(A_{1} R\right)(5)$, as in our patients, many $A_{1} R$ are free. $A_{1} R$ are known to be located within the $A V$ node and, to a lesser extent, in the sinus node, and therefore their activation may cause syncope as a result of prolonged asystolic pauses due to $\mathrm{AV}$ block or sinus arrest $(2,3,4,6,11)$. Theophylline is able to saturate $A_{1} R$, thus preventing an acute increase in plasmatic adenosine (e.g., in the case of myocardial hypoxia or during reflex beta-adrenergic stimulation $[6,11])$ from recruiting a sufficient number of receptors to cause AV 
block or sinus-atrial arrest. In addition, as theophylline is also an almost equally potent antagonist of $A_{2}$ receptors, which are located in the vessels and cause vasodilation, a synergic antagonist action of this drug may also be possible. Conversely, when baseline plasmaadenosine level is high, as in patients with vasovagal syncope or positive tilt testing, most high-affinity $A_{1} R$ are already saturated, and probably desensitized; thus, adenosine release is unlikely to have an effect on A1 receptors and consequently on heart rate $(4,7)$. Thus, from a pathophysiological point of view, xanthine derivatives may probably be less effective, owing to the high dose necessary to displace high concentrations of adenosine from its receptors. Indeed, in an acute study (12) theophylline was ineffective in patients with tilt-induced vasovagal syncope whereas it was partially effective in preventing dipyridamole-induced syncope.

The above considerations could explain the variable efficacy of theophylline therapy reported in the literature in the absence of plasmatic adenosine assay.In 11 patients with recurrent unexplained syncopes and positive ATP test - which suggests an overlap with low adenosine patients - syncope recurred in 2 patients (15\%) during a mean follow-up of 13 months (13). The few small observational studies existing in the literaturein patients with vasovagal syncope report a recurrence rate ranging between $12 \%$ and $22 \%(14,15,16)$. Finally, in a randomized controlled trial (17), theophylline was ineffective in preventing syncope in patients affected by intrinsic sick sinus syndrome compared with no treatment arm.

Some patients in our report differ from the others. Patient \#3 had undocumented syncope, the efficacy of theophylline could only be argued from the dramatic disappearance of symptoms as soon as she started the therapy. Patient \#5 presented with sinus arrest and not AV block and had a cardioinhibitory response with tilt test which suggests a vasovagal mechanism. On the other hand the clinical presentation of syncopes without prodromes (consistent with the ECG documentation of sudden onset sinus arrest) and low plasmatic adenosine are common features with the other patients and theophylline was effective. A joint involvement of both acetylcholinergic and purinergic pathways in this case is possible and has a solid pathophysiologial (6) and clinical $(7,18)$ background in the literature. Patient \#6 was not responsive to theophylline although she had low adenosine plasma levels; the very frequent episodes of paroxysmal AV block observed on each 24-hour Holter recording have features compatible with vagally-induced $(8,9)$ rather than idiopathic AV block(3). However, this case was reported here since it shared the common biological pattern of low plasma adenosine syncope.

\section{Limitations}

The present report has several limitations, mainly due to the small number of patients described and the lack of a homogeneous data collection. Nevertheless, these limitations are partly overcome by the long follow-up - up to several years - the electrocardiographic documentation of syncope in most of the patients and the intrapatient control comparison.

The present report lacks of a formal comparison with patientswith documented episodes paroxysmal AV block and sinus-atrial arrest of known etiology. We reviewed our adenosine database and we found 10 patients with a clinically established diagnosis of reflex syncope who had an ILR documentation of asystolic syncope. In contrast with the patients of the present report, all 9 vasovagal patients had progressive sinus bradycardia followed by sinus arrest; they had high 
adenosine and high expression of A2A adenosine receptors. The patient with swallowing syncope had recurrent paroxysmal AV block similar to our patient \#6 but normal adenosine value (Table 3 ). Furthermore, we found 4 patients who had an intrinsic paroxysmal AV blockdue to degenerative disease of AV conduction system. These patients had normal adenosine values (Table 3). Thus, low adenosine is a typical features of patients with unexplained syncope, no prodrome and normal heart. We argue that in such patients theophylline has little rationale to be as effective as in our patients.

\section{Conclusion and perspectives}

In conclusion, theophylline seems to be able to prevent syncopal recurrences and asystolic events in patients with low-adenosine syncope, and may be considered as an alternative to permanent pacing therapy in such patients. This study provides the rationale for planning a randomized controlled trial aimed at confirming or refuting these results. At present it is unknown how many patients with unexplained syncope are actually "low adenosine" patients who could benefit of theophylline therapy. In the ISSUE 2 and ISSUE 3 studies $(19,20)$, which enrolled patients with suspected or certain neurally-mediated syncope (prodromes were absent in about a half of them), an idiopathic-like paroxysmal AV block was observed in $8 \%$ of patients who had a ILR documentation of syncope and accounted for $22 \%$ of those of had an asystolic event. It is possible that some of these patients were "low adenosine" patients. 


\section{References}

1. Sheldon RS, Grubb BP, Olshansky B et al. 2015 Heart Rhythm Society Expert Consensus statement on the diagnosis and treatment of postural tachycardia syndrome, inappropriate sinus tachycardia, and vasovagal syncope. Heart Rhythm 2015; 12: e41-63

2. Deharo JC, Guieu R, Mechulan A, Peyrouse E, Kipson N, Ruf J, Gerolami V, Devoto G, Marrè V, Brignole M. Syncope without prodromes in patients with normal heart and normal electrocardiogram: a distinct entity. J Am Coll Cardiol 2013; 62:1075-1080

3. Brignole M, Deharo JC, De Roy L, Menozzi C, Blommaert D, Dabiri L, Ruf J, Guieu R. Syncope due to idiopathic paroxysmal atrioventricular block. Long term follow up of a distinct form of atrioventricular block. J Am Coll Cardiol 2011; 58: 167-173.

4. Guieu R, Deharo JC, Ruf J, Mottola G, Kipson N, Bruzzese L, Gerolami V, Franceschi F, Ungar A, Tomaino $\mathrm{M}$, lori $\mathrm{M}$, Brignole $\mathrm{M}$. Adenosine and clinical forms of neurally-mediated syncope. J Am Coll Cardiol 2015; 66: 202-203

5. Cohen FR, Lazareno S, Birdsall NJ. The affinity of adenosine for the high- and low-affinity states of the human adenosine A1 receptors. Eur J Pharmacol 1996; 309: 111-114

6. Lerman B, Belardinelli L. Cardiac electrophysiology of Adenosine. Basic and clinical concepts. Circulation 1991; 83: 1499-1507.

7. Franceschi F, By Y, Peyrouse E, Fromonot J, Gerolami V, Kipson N, Boussuges A, Brignole M, Fenouillet E, Deharo JC, Ruf J, Guieu R. A2A adenosine receptor function in patients with vasovagal syncope. Europace 2013; 15: 1328-1332

8. Lee S, Wellens JJ, Josephson M. Paroxysmal atrioventricular block. Heart Rhythm 2009; 6: $1229-1234$

9. Alboni P, Holz A, BrignoleM. Vagally mediated atrioventricular block: pathophysiology and diagnosis. Heart 2013; 99: 904-908.

10. Daly JW, Jacobson KA, Ukena D. Adenosine receptors: development of selective agonists and antagonists. Prog Clin Biol Res. 1987; 230: 41-63

11. Clemo H, Belardinelli L. Effect of adenosine on atrioventricular conduction. I: site and characterization of adenosine action in the guinea pig atrioventricular node. Circ Res 1986; 59: 427-36. 
12. Sinkovec M, Grad A, Rakovec P. Role of endogenous adenosine in vasovagal syncope. Clin Auton Res 2001; 11: 155-161.

13. Brignole M, Gaggioli G, Menozzi C, Gianfranchi L, Bartoletti A, Bottoni N, Lolli G, Oddone D, Del Rosso A, Pellinghelli G. Adenosine-induced atrioventricular block in patients with unexplained syncope: the diagnostic value of ATP testing. Circulation 1997; 96: 3921-3927

14. Benditt Dg, Benson W, Kreitt J, Dunnigan A, Pritzker MR, Crouse L, Scheinman MM. Electrophysiologic effects of theophylline in young patients with recurrent symptomatic bradyarrhythmias. Am J Cardiol 1983; 52: 1223-1229

15. Sra J, Jazayeri M, Avitali B, Dhala A, Deshpande S, Blanck Z, Akhtar M. Comparison of cardiac pacing with drug therpy in the treatment of neurocardiogenic (vasovagal) syncope with bradycardia or asystole. N Engl J Med 1993; 328: 1085-1090

16. Natale A, Sra J, Dhala A, Wase A, Jazayeri M, Deshpande S, Blanck Z, Akhtar M. Efficacy of different treatment strategies for neurocardiogenic syncope. Pacing Clin Electrophysiol 1995; 18: 655-662.

17. Alboni P, Menozzi C, Brignole M, Paparella N, Gaggioli G, Lolli G, Cappato R. Effects of permanent pacemaker and oral theophylline in sick sinus syndrome the THEOPACE study: a randomized controlled trial. Circulation. 1997; 96: 260-266.

18. Deharo J-C, Mechulan A, Giorgi R, Francheschi F, Prevot S, Peyrouse E, Condo J, By Y, Ruf J, Brignole M, Guieu R. Adenosine plasma level and A2A adenosine receptor expression: correlation with laboratory tests in patients with neurally mediated syncope. Heart 2012; 98: 855-859.

19. Brignole M, Sutton R, Menozzi C, Garcia-Civera R, Moya A, Wieling W, Andresen D, Benditt DG, Vardas P. Early application of an implantable loop recorder allows effective specific therapy in patients with recurrent suspected neurally mediated syncope. Eur Heart J 2006; 27: 1085-1092

20. Brignole $M$, Menozzi $C$, Moya A, et al. Pacemakertherapy in patients with neurally mediated syncopeand documented asystole. Third international studyon syncope of uncertain etiology (ISSUE-3). A randomizedtrial. Circulation 2012;125:2566-2571. 
Figure 1

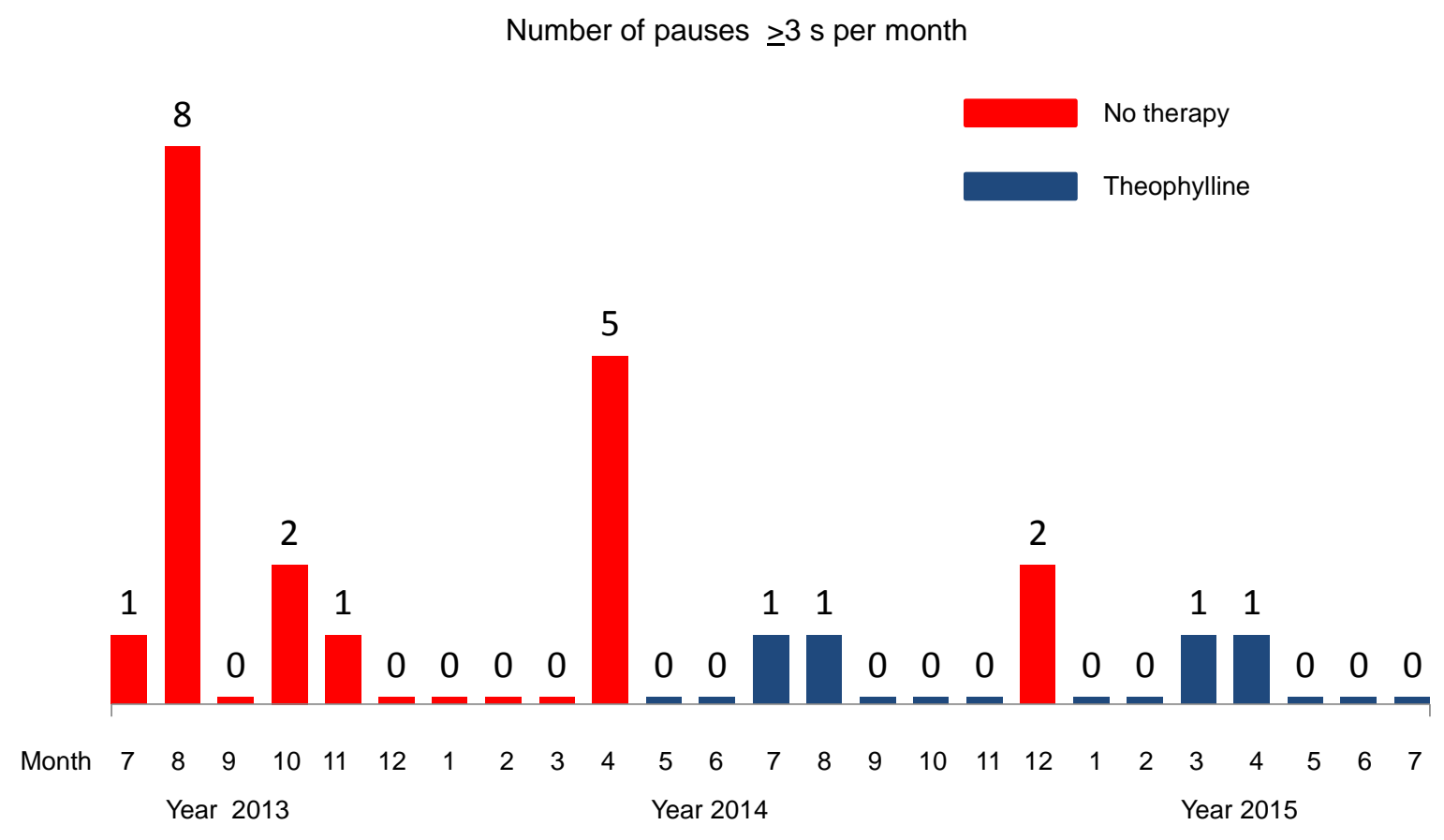

Case \#2, $M, 72$ yrs

Figure 1. Patient \#2, affected by idiopathic paroxysmal $V$ block. This patient participated in a 2period cross-over trial (Off-On-Off-On therapy) under ILR monitoring for a total of 25 months. The histograms show the numbers of episodes per month. Episodes of idiopathic paroxysmal AV block decreased from 19 (max pause $7 \mathrm{~s}$ ) off therapy to 4 (max pause $3 \mathrm{~s}$ ) on therapy. 


\section{Figure 2}

A)
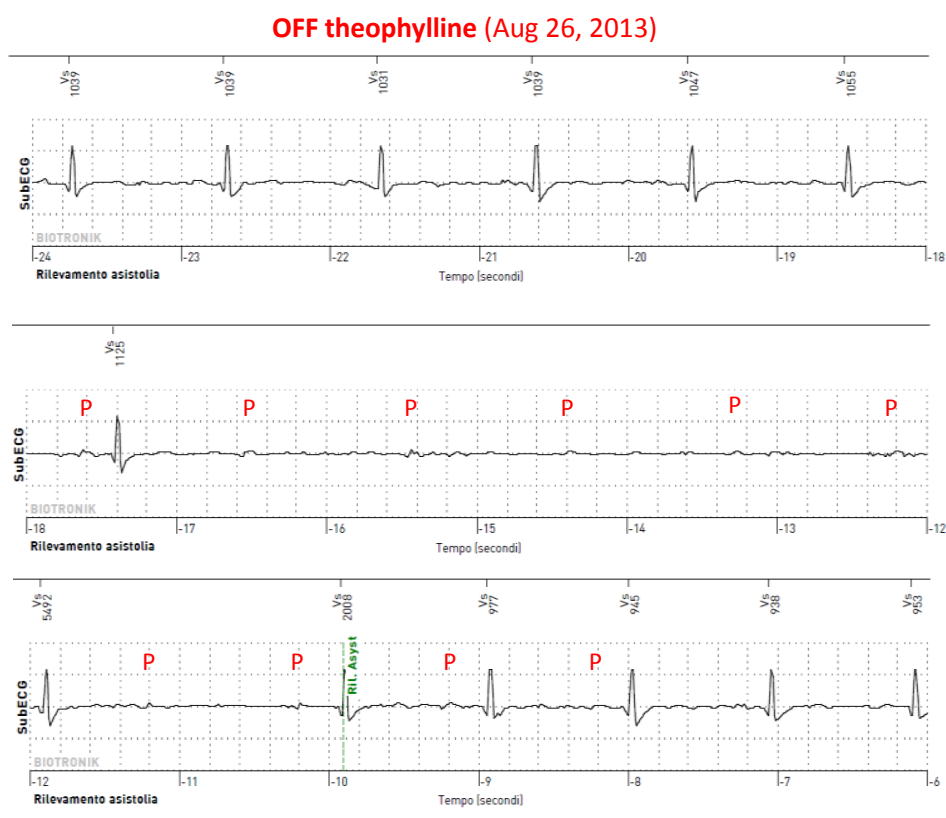

Case \#2, M, 72 yrs

B)
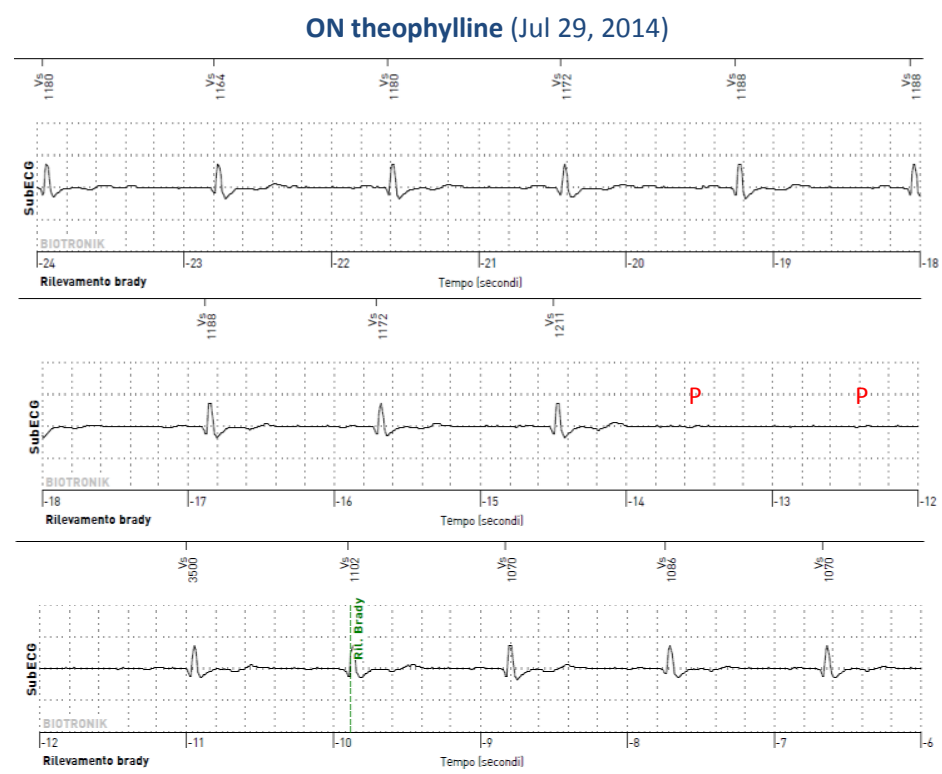

Case \#2, M, 72 yrs 
C)
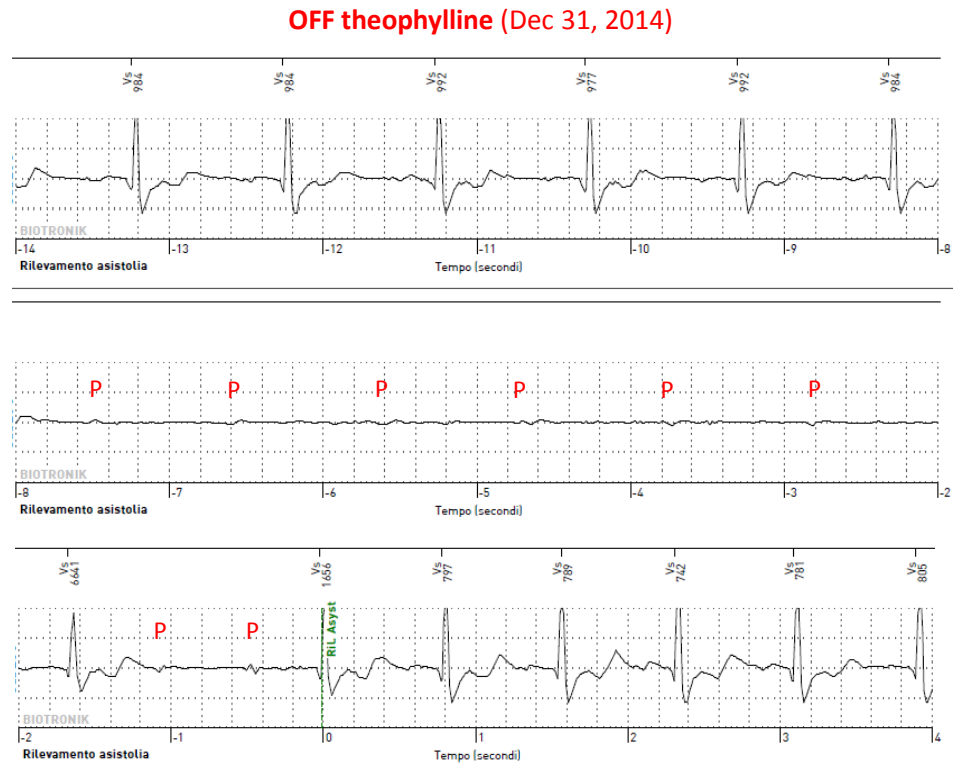

Case \#2, $M, 72$ yrs

Figure 2. Same patient as figure 1. The panels show examples of typical idiopathic paroxysmal AV block characterized by sudden-onset AV block without R-R cycle changes and constant PR interval. Panel A : Recording during the first period Off therapy: 4 consecutive $P$ waves are blocked (pause of $7 \mathrm{~s}$ ) and are followed by a conducted beat and then by another single blocked P wave. Panel B. Recording during the first period On therapy: the blocked $P$ waves are reduced to 2 and the maximum pause is of $3 \mathrm{~s}$. Panel $\mathbf{C}$. Recording during the second period Off therapy. The episode resembles that of the first Off period: 6 consecutive $P$ waves are blocked (pause of $6 \mathrm{~s}$ ) and are followed by a conducted beat and then by another single blocked $\mathrm{P}$ wave. 


\section{Figure 3}

Number of pauses $\geq 3$ s per month

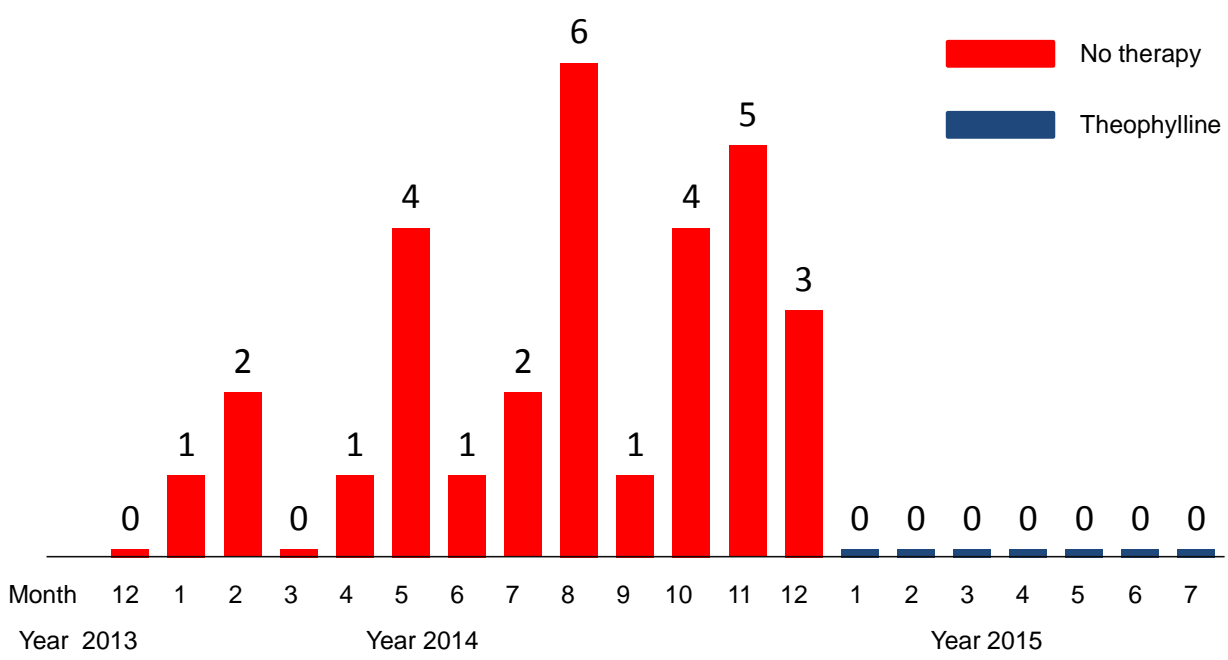

Case \#4, F, 71 yrs

Figure 3. Patient \#4, affected by idiopathic paroxysmal V block. This patient participated in a crossover trial (Off-On therapy) under ILR monitoring for a total of 20 months. The histograms show the numbers of episodes per month. A total of 27 episodes of idiopathic paroxysmal AV block (max pause $7 \mathrm{~s}$ ) occurred in the 13-month period off therapy; episodes disappeared completely as soon as the patient started theophylline therapy. 


\section{Figure 4}
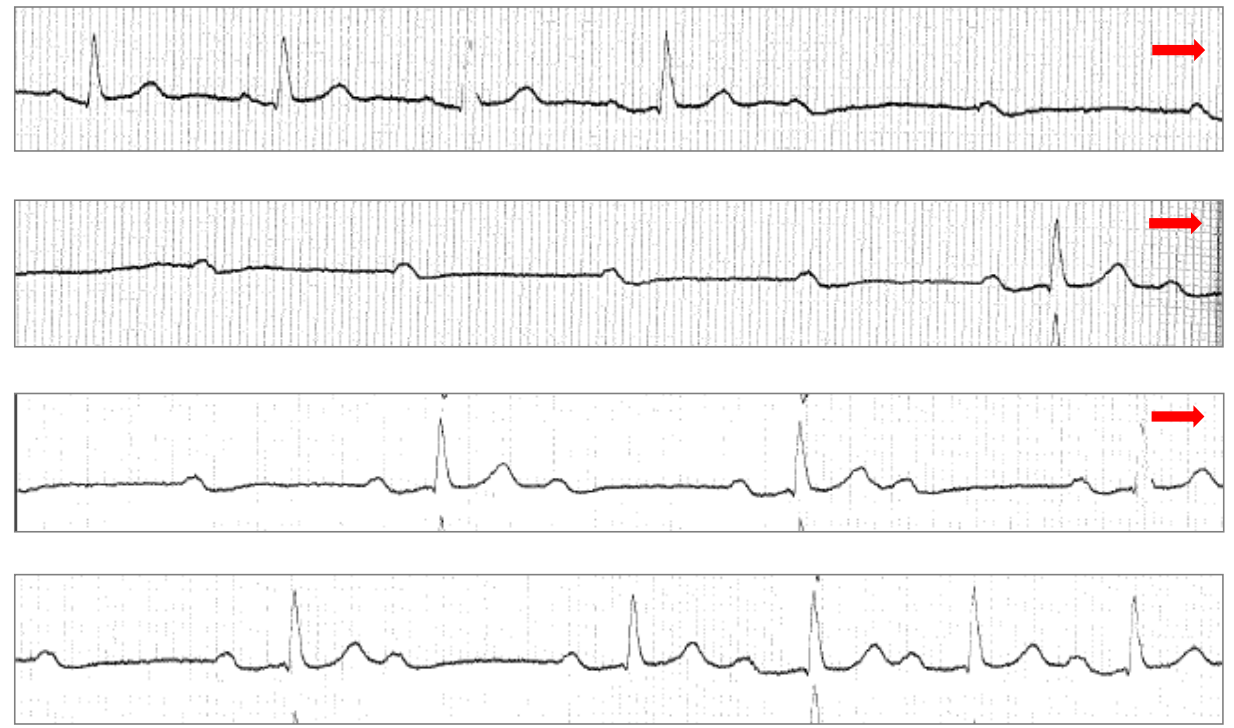

Figure 4. Case \#6. The continuous ECG tracing (lead II) shows an episode of paroxysmal AV block. In this patient, too, AV block occurred without P-P cycle changes; unlike case \#4, however, the PR interval lengthens before block, from $0.20 \mathrm{~s}$ to $0.28 \mathrm{~s}$ in the beat immediately preceding the asystolic pause. Furthermore, the asystolic pause is followed by 2:1 AV block and then $1^{\text {st }}$ degree AV block with prolonged PR interval up to $0.36 \mathrm{~s}$ in the conducted beats. PR prolongation is suggestive of vagal AV block $(8,9)$ rather than adenosine AV block or idiopathic AV block $(3)$. For comparison, see case 2 , figure 1 . 
Table 1. Characteristics of the 6 "low-adenosine" patients who were treated with theophylline

\begin{tabular}{|c|c|c|c|c|c|c|c|}
\hline $\begin{array}{l}\text { No, gender, } \\
\text { age }\end{array}$ & $\begin{array}{l}\text { ECG } \\
\text { documentation of } \\
\text { the index event, } \\
\text { (total duration/ } \\
\text { longest pause) * }\end{array}$ & $\begin{array}{l}\text { Adenosine } \\
\text { plasmatic level, } \\
\mu \mathrm{mol} / \mathrm{L} \\
\text { (normal range: } \\
0.40-0.78 \text { ) }\end{array}$ & $\begin{array}{l}\text { A2 A adenosine } \\
\text { receptor } \\
\text { expression, AU } \\
\text { (normal range: } \\
0.40-0.80 \text { ) }\end{array}$ & $\begin{array}{l}\text { Adenosine } \\
\text { i.v. test, } \\
\text { max pause }\end{array}$ & $\begin{array}{c}\text { Tilt table } \\
\text { test }\end{array}$ & $\begin{array}{l}\text { Carotid sinus } \\
\text { massage }\end{array}$ & $\begin{array}{l}\text { Electro- } \\
\text { physiological } \\
\text { study }\end{array}$ \\
\hline$\# 1 . F, 50$ yrs & $\begin{array}{l}\text { Idiopathic AVB } \\
\text { (34/22 s) }\end{array}$ & 0.12 & 0.20 & $11 \mathrm{~s}$ & negative & negative & negative \\
\hline \#2. M, 72 yrs & $\begin{array}{l}\text { Idiopathic AVB } \\
(11 / 7 \mathrm{~s})\end{array}$ & 0.09 & 0.50 & neg & negative & negative & negative \\
\hline \#3. F, 20 yrs & $\begin{array}{l}\text { none (ILR only } \\
\text { with theophylline) }\end{array}$ & 0.09 & 0.55 & $5.4 \mathrm{~s}$ & negative & $\mathrm{np}$ & negative \\
\hline \#4. F, 71 yrs & $\begin{array}{l}\text { Idiopathic AVB } \\
(24 / 7 \mathrm{~s})\end{array}$ & 0.10 & $\mathrm{np}$ & $7 \mathrm{~s}$ & $\begin{array}{l}\text { positive } \\
\text { mixed }\end{array}$ & negative & $\mathrm{np}$ \\
\hline \#5. M, 41 yrs & $\begin{array}{l}\text { Sinus arrest (18/6 } \\
\text { s) }\end{array}$ & 0.18 & 0.80 & $7.4 \mathrm{~s}$ & $\begin{array}{c}\text { positive } \\
\text { cardioinhib. }\end{array}$ & negative & $\mathrm{np}$ \\
\hline \#6. F, 52 yrs & $\begin{array}{l}\text { Paroxysmal AVB } \\
(-/ 9 \mathrm{~s})\end{array}$ & 0.10 & 0.45 & $7.6 \mathrm{~s}$ & negative & negative & negative \\
\hline
\end{tabular}

* documentation with prolonged monitoring by means of implantable loop recorder (ILR) in cases 1,2,4 and 5 and Holter monitoring in case 6

AVB = atrioventricular block; $\mathrm{np}=$ not performed

Adenosine plasma level was evaluated by means of high-performance liquid chromatography, as previously described [2]. Adenosine

$A_{2}$ receptor expression was evaluated by western blot, as previously described (7). The normal ranges are between the $5^{\text {th }}$ and $95^{\text {th }}$ percentiles of the values recorded in healthy control subjects (4). 
Table 2. Comparative effect on outcome in 5 patients who responded to theophylline and the one who did not

\begin{tabular}{|c|c|c|c|c|c|c|c|c|}
\hline \multirow{2}{*}{ Pt no, } & \multicolumn{2}{|c|}{$\begin{array}{l}\text { History of syncope } \\
\text { before diagnosis }\end{array}$} & \multicolumn{3}{|c|}{ Observation without therapy } & \multicolumn{3}{|c|}{ Observation during theophylline therapy } \\
\hline & $\begin{array}{c}\text { Duration, } \\
\text { years }\end{array}$ & $\begin{array}{c}\text { no. of } \\
\text { episodes }\end{array}$ & Months & $\begin{array}{l}\text { Episodes of } \\
\text { syncope }\end{array}$ & $\begin{array}{l}\text { Episodes of } \\
\text { asystole } \geq 3 \mathrm{~s}^{*}\end{array}$ & Months & $\begin{array}{l}\text { Episodes of } \\
\text { syncope }\end{array}$ & $\begin{array}{l}\text { Episodes of } \\
\text { asystole } \geq 3 \mathrm{~s}^{*}\end{array}$ \\
\hline$\# 1$ & 30 & 20 & 36 & 4 & 3 & 120 & 0 & $\mathrm{np}$ \\
\hline \#2 & 12 & 2 & 11 & 0 & 19 & 14 & 0 & 4 \\
\hline \#3 & 18 & 40 & 24 & 8 & $\mathrm{np}$ & 24 & 0 & 0 \\
\hline$\# 4$ & 1 & 2 & 13 & 0 & 27 & 6 & 0 & 0 \\
\hline \#5 & 3 & 5 & 2 & 1 & 1 & 20 & 0 & 0 \\
\hline $\begin{array}{l}\text { Median } \\
\text { (IQR) }\end{array}$ & $12(3-18)$ & $5(2-20)$ & $\begin{array}{c}13(11- \\
24)\end{array}$ & $0.11(0-0.33)$ & $1.11(0.4-1.8)$ & $20(14-24)$ & $0(0-0)$ & $0(0-0.7)$ \\
\hline \#6 & 2.5 & $\begin{array}{c}\text { Frequent } \\
\text { pre-syncopes }\end{array}$ & 6 & $\begin{array}{l}\text { Frequent } \\
\text { pre-syncopes }\end{array}$ & $\begin{array}{l}14 \text { per day (max } \\
\text { pause } 9.2 \mathrm{~s} \text { ) }\end{array}$ & 1.5 & $\begin{array}{c}\text { Frequent } \\
\text { pre-syncopes }\end{array}$ & $\begin{array}{c}7 \text { per day } \\
\text { (max pause } 6.7 \mathrm{~s})\end{array}$ \\
\hline
\end{tabular}

* observation with prolonged monitoring by means of implantable loop recorder (ILR) in cases 1-5 and Holter monitoring in case 6

$\mathrm{np}=$ not performed; IQR = interquartile range

Wilcoxon matched-pairs signed rank test: too few cases to use this test 
Table 3. Comparative clinical and laboratory findings in a control group of patients affected by ECG-documented asystolic vasovagal/situational syncope or intrinsic cardiac paroxysmal atrioventricular block

\begin{tabular}{|c|c|c|c|c|c|c|c|}
\hline $\begin{array}{l}\text { Pat. number } \\
\text { gender, } \\
\text { age }\end{array}$ & Etiology & Clinical features & $\begin{array}{l}\text { History of } \\
\text { syncope } \\
\text { (duration, yrs / } \\
\text { number of } \\
\text { episodes) }\end{array}$ & $\begin{array}{l}\text { ECG } \\
\text { documentation of } \\
\text { the index event, } \\
\text { (longest pause) }\end{array}$ & $\begin{array}{l}\text { Adenosine } \\
\text { plasmatic } \\
\text { level, } \mu \mathrm{mol} / \mathrm{L} \\
\text { (normal range: } \\
0.40-0.78 \text { ) }\end{array}$ & $\begin{array}{l}\text { A2 A adenosine } \\
\text { receptor } \\
\text { expression, AU } \\
\text { (normal range: } \\
0.40-0.80 \text { ) }\end{array}$ & Tilt testing \\
\hline \#1. M, 69 yrs & Reflex & VVS (typical long prodromes) & $1 / 5$ & $\begin{array}{l}\text { Brady + Sinus arrest } \\
(8 \mathrm{~s})\end{array}$ & 0.90 & 1.1 & positive mixed \\
\hline \#2. M, 32 yrs & Reflex & VVS (typical long prodromes) & $\begin{array}{l}\text { Since chiildwood / } \\
20\end{array}$ & $\begin{array}{l}\text { Brady + Sinus arrest } \\
(16 \mathrm{~s})\end{array}$ & 1.20 & - & positive asystole \\
\hline \#3. F, 71 yrs & Reflex & VVS (typical long prodromes) & $\begin{array}{l}\text { Since chiildwood / } \\
1 \text { last year }\end{array}$ & $\begin{array}{l}\text { Brady }+ \text { Sinus } \\
\text { arrest }(5 \mathrm{~s})\end{array}$ & $1.9 / 1.2$ & 0.98 & positive mixed \\
\hline$\# 4 . F, 68$ yrs & Reflex & VVS (typical long prodromes) & $\begin{array}{l}\text { Since chiildwood / } \\
7 \text { last year }\end{array}$ & $\begin{array}{l}\text { Brady + Sinus arrest } \\
(38 \mathrm{~s})\end{array}$ & 1.39 & $1.4 / 1.5$ & positive mixed \\
\hline \#5. M, 44 yrs & Reflex & VVS (typical long prodromes) & $5 / 3$ & $\begin{array}{l}\text { Brady + Sinus arrest } \\
(6.5 \mathrm{~s})\end{array}$ & 1.67 & - & negative \\
\hline \#6. M, 53 yrs & Reflex & VVS (typical long prodromes) & $5 / 3$ & $\begin{array}{l}\text { Brady + Sinus arrest } \\
(3.5 \mathrm{~s})\end{array}$ & 0.97 & - & negative \\
\hline \#7. M, 59 yrs & Reflex & VVS (typical long prodromes) & $14 / 8$ & $\begin{array}{l}\text { Brady + Sinus arrest } \\
(5.5 \mathrm{~s})\end{array}$ & 1.24 & - & negative \\
\hline \#8. F, 83 yrs & Reflex & Post-prandial & $4 / 4$ & Bradycardia 30 bpm & 0.98 & - & positive asystole \\
\hline \#9. M, 43 yrs & Reflex & $\begin{array}{l}\text { Aypical VVS (atypical short } \\
\text { prodromes, supine, long } \\
\text { recovery) }\end{array}$ & $1 / 5$ & $\begin{array}{l}\text { Brady + AVB + sinus } \\
\text { arrest (42 s) }\end{array}$ & 1.90 & - & negative \\
\hline \#10.F, 33 yrs & Reflex & $\begin{array}{l}\text { Swallowing syncope } \\
\text { (reproduced with active } \\
\text { swallow) }\end{array}$ & $\begin{array}{l}\text { Since chiildwood / } \\
>20\end{array}$ & $\begin{array}{l}\text { Daily narrow QRS } \\
\text { AVB (4 s) }\end{array}$ & 0.6 & 0.45 & positive mixed \\
\hline$\# 11 . \mathrm{M}, 80$ yrs & Cardiac & $\begin{array}{l}\text { Intrinsic AV conduction } \\
\text { disease }\end{array}$ & No & $\begin{array}{l}\text { Narrow QRS } \\
\text { paroxysmal AVB }\end{array}$ & 0.45 & - & not performed \\
\hline$\# 12 . F, 79$ yrs & Cardiac & $\begin{array}{l}\text { Intrinsic AV conduction } \\
\text { disease }\end{array}$ & $0.1 / 1$ & $\begin{array}{l}\text { Narrow QRS } \\
\text { paroxysmal AVB }\end{array}$ & 0.70 & - & not performed \\
\hline \#13.F, 79 yrs & Cardiac & $\begin{array}{l}\text { Intrinsic AV conduction } \\
\text { disease and aortic stenosis }\end{array}$ & No & $\begin{array}{l}\text { Wide QRS } \\
\text { paroxysmal AVB }\end{array}$ & 0.45 & - & not performed \\
\hline \#13.F, 84 yrs & Cardiac & $\begin{array}{l}\text { Intrinsic AV conduction } \\
\text { disease and hypertension }\end{array}$ & No & $\begin{array}{l}\text { Narrow QRS } \\
\text { paroxysmal AVB }\end{array}$ & 0.35 & - & not performed \\
\hline
\end{tabular}

